\title{
HUBUNGAN ANTARA RELIGIUSITAS DENGAN KEBERMAKNAAN HIDUP NARAPIDANA DI LEMBAGA PEMASYARAKATAN (LAPAS) KELAS 1 SEMARANG
}

\author{
Candra Ayu Kusumastuti dan Rohmatun \\ Fakultas Psikologi Universitas Islam Sultan Agung, Jl. Kaligawe Raya, Km. 4 Kota Semarang 50112 \\ Email: rohmatun@unissula.ac.id
}

\begin{abstract}
Abstrak
Penelitian ini bertujuan untuk mengetahui hubungan antara religiusitas dengan kebermaknaan hidup narapidana. Penelitian ini menggunakan metode kuantitatif korelasional dengan subjek berjumlah 135 narapidana. Teknik dalam pengambilan sampel menggunakan teknik cluster random sampling. Metode pengumpulan data menggunakan skala kebermaknaan hidup dan religiusitas. Skala kebermaknaan hidup berjumlah 20 aitem berdaya beda tinggi dengan koefisien korelasi skor aitem total bergerak antara 0,311 - 0,553 dengan reliabilitas 0,827 . sedangkan skala religiusitas berjumlah 44 aitem berdaya beda tinggi dengan koefisien korelasi skor aitem total bergerak antara 0,308-0, 688 dengan skor reliabilitas sebesar 0, 939. Uji hipotesis menggunakan teknik analisis Product Moment dengan $r_{x y}=0,684$ dengan taraf signifikansi $p=0,000(p<0,01)$ yang menunjukkan ada hubungan positif yang signifikan antara religiusitas dengan kebermaknaan hidup narapidana di LAPAS kelas 1 Semarang. Variabel religiusitas memberikan sumbangan efektif sebesar 46,7 \% terhadap kebermaknaan hidup, sisanya 53,3\% dipengaruhi oleh faktor yang lain.
\end{abstract}

Kata Kunci : Kebermaknaan Hidup, Religiusitas

\section{RELATIONSHIP BETWEEN RELIGIOSITY AND LIFE MEANING AMONG INMATES IN CLASS ONE PENITENTIARY SEMARANG}

\begin{abstract}
This study aimed to determine the relationship between religiosity and meaningfulness of the prisoner's live. This study used correlative quantitative method with 135 subjects of inmates and the technique of this study used Cluster random sampling technique. The method that used in this study was the scale of meaningfulness of live and religiosity. The scale of meaningfulness of live amounted to 20 coefficient of item-total correlation between $0.311-0,553$ with reliability score about 0.827 . Meanwhile the scale of religiosity amounted to 44 coefficient of item-total correlation between $0.308-0,688$ with reliability score about 0,939 . Hypothesis test of this study used Product Moment analysis technique with rxy $=0,684$ with significance level $p=0,000(p<0,01)$ indicating there was positive relationship which is significance between religiosity and meaningfulness of prisoners in 1 st class of correctional institution (LAPAS) Semarang. Religiosity variable give effective contribution equal to $46,7 \%$ to meaningfulness of live, the rest 53,3\% influenced by other factor.
\end{abstract}

Keywords: Meaningfulness of Life, Religiosity 


\section{Pendahuluan}

Setiap warga harus mengikuti aturan dan hukum yang berlaku sehingga setiap warga negara memiliki tingkatan yang sama didepan hukum. Hal ini selaras dengan UUD 1945 pasal 27 ayat 1,

"Segala warga negara bersamaan kedudukannya di dalam hukum dan pemerintahan dan wajib menjunjung hukum dan pemerintahan itu dengan tidak ada kecuali" (UUD 45 Pasal 27 ayat 1).

Kenyataan yang terjadi di Indonesia banyak warga negara yang melanggar hukum dan tidak sesuai dengan undang undang yang berlaku (Moeljatno, 2008). Perbuatan yang melanggar hukum dan dilarang dengan berupa sanksi yang berlaku disebut tindak pidana, beberapa tindakan pidana tersebut adalah kasus kejahatan dan pelanggaran (Moeljatno, 2008). Sumber-sumber kejahatan disebabkan oleh kemiskinan, kekayaan yang tidak merata, peperangan dan pemberontakan (Muljono, 2012). Syani (1987) juga mengatakan bahwa faktor-faktor yang mempengaruhi tindak kejahatan yaitu faktor internal yaitu berupa keadaan psikologis diri individu dan sifat umum pada diri individu dan faktor eksternal terdiri atas faktor ekonomi, faktor agama, faktor bacaan dan faktor film.

Berdasarkan hasil data BPS (Badan Pusat Statistika) yang diperoleh dari Kepolisian Daerah pada tahun 2000 hingga 2015 kasus tindakan pidana di Indonesia mengalami peningkatan yang semula 172.532 kasus menjadi 352.936 kasus (www. bps.go.id). Kasus tindakan pidana di Jawa Tengah juga semakin meningkat ditunjukkan dari hasil BPS (Badan Pusat Statistika) yang didapat dari Kepolisian Daerah Jawa Tengah pada tahun 2000 sampai 2015 yaitu 12713 kasus sampai 15958 kasus (www.bps.go.id). Seseorang yang sedang menjalani hukuman pidana berupa sanksi dari kejahatan yang diperbuat atau pelanggaran yang dilakukan disebut Narapidana. Narapidana merupakan terpidana yang sedang melaksanakan sanksi pidana di Lembaga Pemasyarakatan (UU RI No. 12 Tahun 1995 tentang Pemasyarakatan Pasal 1 ayat 7). UU Nomor 12 Tahun 1995 tentang Pemasyarakatan pasal 1 ayat 2 LAPAS atau Lembaga Pemasyarakatan ialah tempat untuk dilakukan pembinaan Narapidana dan Anak Didik Pemasyarakatan.

Lamintang (dalam Priyatno, 2006) menyatakan bahwa narapidana mengalami pembatasan kebebasan bergerak dengan menutup narapidana tersebut di dalam sebuah lembaga pemasyarakatan, narapidana diwajibkan untuk mengikuti semua peraturan tata tertib yang dilakukan di lembaga pemasyarakatan, yang terkait dengan tindakan tata tertib bagi mereka yang telah melanggar peraturan tersebut.

Wilson (dalam Pinasthika, 2013) mengemukakan narapidana merupakan individu yang dikatakan bermasalah sehingga dipisahkan dari masyarakat supaya bisa merubah tingkah laku lebih baik dan kembali kemasyarakat. Sedangkan menurut Dirjosworo (dalam Pinasthika, 2013) narapidana yaitu individu pada umumnya sama halnya dengan indivdu lainnya tetapi hakim menjatuhi hukuman karena melanggar hukum dan norma yang berlaku.

Priyatno (2006) menjelaskan bahwa dampak yang diakibatkan oleh hilangnya kemerdekaan narapidana yaitu kehidupan sosial ekonomi keluarga tergannggu, stigma atau label yang akan terus melekat dan pengalaman selama di penjara yang dapat mempengaruhi harga diri seseorang. Madjid (1996) menyatakan tekanan berlebihan yang dialami narapidana menjadi penyebab terjadinya suatu permasalahan dalam memaknai kehidupan dan menjadikan narapidana kehilangan kesadaran yang mendalam untuk dapat memaknai hidup.

178 
Hubungan Antara Religiusitas Dengan Kebermaknaan Hidup Narapidana di Lembaga Pemasyarakatan (Lapas) Kelas 1 Semarang Proyeksi, Vol. 13 (2) 2018, 177-186

Kebermaknaan hidup sendiri adalah individu yang mampu menjalani kehidupan bermakna dan memiliki kebermaknaan hidup akan lebih mengenali diri sendiri dan menerima kekurangan dirinya (Schultz, 1995). Sedangkan Prihastiwi (1994) mengatakan bahwa kebermaknaan hidup yaitu merupakan suatu kualitas penghayatan individu terhadap apa yang telah dilakukan sebagai upaya mengaktualisasikan potensinya, merealisasikan nilai-nilai dan tujuan melalui kehidupan yang penuh kreatifitas dalam rangka pemenuhan diri (self fulfillment). Frankl (2003) mengemukakan bahwa kebermaknaan hidup dapat dicapai melalui pengalaman spiritual. Frankl menekankan bahwa pengalaman spiritual membentuk dan memuaskan will to mean ini, tidak ada kebermaknaan hidup sejati atau (kehendak untuk hidup bermakna).

Wilson (dalam Pinasthika, 2013) mengemukakan narapidana merupakan individu yang dikatakan bermasalah sehingga dipisahkan dari masyarakat supaya bisa merubah tingkah laku lebih baik dan kembali kemasyarakat. Sedangkan menurut Dirjosworo (dalam Pinasthika, 2013) narapidana yaitu individu pada umumnya sama halnya dengan indivdu lainnya tetapi hakim menjatuhi hukuman karena melanggar hukum dan norma yang berlaku.

Seseorang mampu menemukan makna tentang suatu kebenaran dengan mengamalkan nilai-nilai yang berasal dari agama (Ula, 2014). Kebermaknaan hidup dipengaruhi oleh beberapa hal diantaranya adalah religiusitas (Ula, 2014). Religiusitas berdasarkan Nashori dan Diana (2002) yaitu sebanyak apa melaksanakan ibadah dengan kaidah, sejauh mana penghayatan atas agaam yang dianut, sejauh apa pengalaman, seteguh apa keyakinannya. Ancok dan Nashori (2008) menjelaskan religiusitas mempunyai lima dimensi yaitu syariah, akhlak, akidah, pengetahuan agama dan penghayatan. Seseorang yang memiliki religiusitas yang baik dengan menyakini Tuhan yang Maha Esa dan agama yag menjadi sumber-sumber untuk memamaknai kehidupan pribadi akan memiliki makna hidup yang sempurna (Bastaman, 2007). Religiusitas yang baik pada individu dengan menjalankan semua diperintahkan oleh Tuhan dan menjauhi larangan Tuhan maka memiliki kebermaknaan hidup yang baik dengan mampu memberikan manfaat bagi sesama manusia dan Alam semesta (Nashori \& Diana, 2002).

Penelitian tentang kebermaknaan hidup sudah banyak dilakukan diantaranya oleh (Uyun \& Gumilar, 2009) dengan judul kebersyukuran dan kebermaknaan hidup pada mahasiswa menunjukkan bahwa ada hubungan signifikan antara kebersyukuran dan kebermaknaan hidup pada mahsiswa universitas islam indonesia. Tobing \& Dewi (2014) melakukan penelitian dengan judul Kebermaknaan hidup pada anak pidana di Bali menunjukkan bahwa kebermaknaan hidup bagi anak pidana yang menjalani masa pembinaan di dalam Lembaga Pemasyarakatan Anak Kleas II B terdiri atas enam aspek, yaitu aspek kepuasan hidup, hal yang paling berarti dalam hidup, kebebasan, kepantasan untuk hidup, perubahan yang dialami dan penerimaan terhadap kehidupan di dalam LAPAS.

Selain itu penelitian sebelumnya yang dilakukan oleh (Hidayati \& Nurhidayah, 2009) yang berjudul hubungan antara ketabahan dan Locus Of Control External dengan kebermaknaan hidup pada istri yang bekerja di bagian Sewing pada PT. Bosaeng Jaya Bantar Gebang Bekasi diperoleh hasil bahwa terdapat hubungan positif antara ketabahan dengan kebermaknaan hidup pada istri yang bekerja di bagian Sewing pada PT. Bosaeng Jaya Bantar Gebang Bekasi dan tidak ada hubungan antara Locus Of Control External dengan kebermaknaan hidup pada istri yang bekerja di bagian Sewing pada PT. Bosaeng Jaya Bantar Gebang Bekasi. 


\section{Kebermaknaan Hidup}

Koeswara (dalam Bukhori, 2012) mengatakan kebermaknaan hidup adalah upaya individu menjiwai eksistensinya, melingkupi hal-hal berarti dan berharga serta mampu memberikan arti khusus dalam tujuan hidupnya. Sedangkan Bastaman (2007) menjelaskan makna hidup merupakan sesuatu yang sangat penting dan berharga untuk individu serta memberikan nilai khusus yang dapat dijadikan tujuan pada kehidupannya.

Frankl (dalam Pratiwi, 2011) memaparkan bahwa kebermaknaan hidup merupakan komitmen hidup yang harus dimiliki individu supaya terbentuk sebuah kekuatan untuk kehidupannya. Hal ini bagian dari alasan individu untuk selalu bertahan hidup. Kebermaknaan hidup bisa diterapkan pada keinginan seseorang untuk menjadi individu yang bermanfaat bagi sesama manusia. Seseorang yang dapat merasakan kehidupannya bermakna, dapat mempunyai komitmen untuk kehidupan yang lebih berarti dan maju.

Menurut Frankl (2003) kebermaknaan hidup manusia disebabkan oleh beberapa faktor, antara lain tanggung jawab seseorang dalam mengambil suatu pilihan dan memanfaatkan waktu sebaik mungkin, spiritualitas, serta kebebasan.

Bastaman (2007) mengungkapkan bawha kebermaknaan hidup terdiri dari 3 (tiga ) komponen, yakni kehendak hidup bermakna, kebebasan berkehendak dan makna hidup. Kehendak hidup bermakna ialah individu yang merasa bahwa dirinya berharga, penting serta mempunyai tujuan yang jelas. Kehendak hidup bermakna adalah keinginan setiap individu yang mampu mendorong untuk bekerja dan berkarya serta melaksanakan hal-hal yang utama dengan harapan hidupnya berharga dan memiliki makna. Oleh sebab itu, individu menganggap motivasi sebagai sesuatu yang penting. Kebebasan berkehendak merupakan orang bebas untuk memilih pilihan-pilihan lainnya yang tersedia sehingga, seseorang memiliki peran yang besar dalam menentukan nasib dirinya sendiri. Terakhir, makna hidup adalah hal yang dianggap baik, perlu serta diharapkan mempunyai skor spesifik untuk seseorang. Jika terpenuhi kehidupan akan begitu berharga, berarti dan menjadi tujuan hidup.

\section{Religiusitas}

Nashori dan Diana (2002) mengatakan religiusitas adalah seseorang yang menganut suatu agama itu dengan menyakini mengetahui tentang agama yang dianut dan menjalankan ibadah sesuai dengan kaidah dalam agama. Sedangkan menurut Wong McDonal dkk (dalam Utami \& Amawidyawati, 2012) religiusitas adalah suatu cara individu menggunakan keyakinannya dalam mengelolah stres dan masalah masalah dalam kehidupan.

Glock dan Stark (dalam Mukhlis \& Istiqomah, 2015) menyatakan bahwa religiusitas terdiri dari 5 (lima) dimensi, yakni:

a. Dimensi praktik agama atau ritualistik, yang merupakan suatu dimensi perilaku pemujaan, ketaatan dan hal-hal yang dilakukan orang untuk menunjukkan komitmen terhadap agama yang dianutnya

b. Dimensi ideologi yaitu pengharapan-pengharapan, orang-orang religius berpegang teguh pada pandangan teologis tertentu dan mengakui adanya doktrin-doktrin tersebut

c. Dimensi pengalaman berupa perasaan-perasaan, pengalaman keagamaan, persepsi-persepsi, dan sensasi-sensasi yang dialami atau didefinisikan oleh suatu kelompok keagamaan dengan Tuhan

d. Dimensi pengamalan atau konsekuensi, yang merupakan suatu pola identifikasi akibat-akibat keyakinan keagamaan, praktik, pengalaman dan pengetahuan seseorang dari waktu ke waktu 
Hubungan Antara Religiusitas Dengan Kebermaknaan Hidup Narapidana di Lembaga Pemasyarakatan

e. Dimensi pengetahuan agama, yakni suatu dimensi yang mengacu pada harapan bahwa individu yang beragama paling tidak memiliki sejumlah minimal pengetahuan mengenai dasar-dasar keyakinan, ritusritus, kitab suci dan tradisi-tradisi.

\section{Metode Penelitian}

Metode pengumpulan data berupa skala kebermaknaan hidup yang terdiri dari 20 aitem berdaya beda tinggi dengan kisaran nilai 0,329-0,519 dan skala religiusitas yang terdiri dari 44 aitem berdaya beda tinggi dengan rentang koefisien daya diskriminasi aitem bergerak antara 0,307-0, 687. Teknik uji daya beda aitem dihitung dengan menggunakan formula korelasi Product Moment. Koefisien reliabilitas item menggunakan teknik alpha cronbach untuk mengetahui koefisien reliabilitas. Teknik analisis data dalam penelitian ini menggunakan teknik analisis product moment. Perhitungan statistik dalam penelitian ini menggunakan bantuan program komputer SPSS (Statistical Product and Service Solution) versi 21.0 .

\section{Hasil}

Penelitian ini bertujuan untuk mengetahui apakah ada hubungan antara religiusitas dengan kebermaknaan hidup narapidana di Lembaga Pemasyarakatan (LAPAS) Kelas 1 Semarang. Sebelum dilakukan uji hipotesis, dilakukan uji asumsi terlebih dahulu. Uji asumsi merupakan analisis yang dilakukan sebelum menguji hipotesis. Uji asumsi yang akan dilakukan terdiri dari uji normalitas dan uji linearitas.

Uji normalitas dilakukan karena peneliti ini mengetahui penyebaran skor aitem data dari variabel penelitian berdistribusi normal atau tidak. Data yang diperoleh pada penelitian ini diuji normalitasnya menggunakan teknik One Sample Kolmogorov Smirnov Z dengan taraf signifikansi lebih besar dari 5\% atau 0,05, maka hasil data tersebut dapat dikatakan berdistribusi secara normal (Hadi, 2012). Bersumber pada hasil perhitungan uji normalitas yang telah dilakukan pada kedua variabel dalam penelitian ini, dapat dilihat pada tabel sebagai berikut:

Tabel 1. Hasil Uji Normalitas

\begin{tabular}{lllllll}
\hline Variabel & Mean & SD & KS-Z & Sig. & P & Ket. \\
\hline $\begin{array}{l}\text { Kebermaknaan } \\
\text { hidup }\end{array}$ & 68,51 & 5,725 & 0,801 & 0,543 & $>0,05$ & Normal \\
\hline Religiusitas & 149,63 & 11,831 & 0,508 & 0,959 & $>0,05$ & Normal \\
\hline
\end{tabular}

Hasil uji normalitas yang didapatkan dari data kebermaknaan hidup menujukkan nilai KS-Z sebesar 0,801 dengan taraf signifikansi sebesar 0,543 (pada $p>0,05$ ) dan data religiusitas menunjukkan nilai KS$Z$ sebesar 340,508 dengan taraf signifikansi sebesar 0,959 (pada $p>0,05$ ). Sehingga peneliti mempunyai data pada kedua variabel yang memiliki distribusi data normal.

Uji asumsi yang dilaksanakan seterusnya adalah uji linearitas, yang memiliki tujuan untuk mengetahui hubungan antara variabel bebas dan variable tergantung dengan menggunakan uji $F$. Linearitas diuji dengan menggunakan program SPSS versi 21,0 for Windows. Taraf signifikansi suatu variabel dikatakan linear apabila $p<0,05$ ) maka dapat disimpulkan bahwa hubungan antara variabel religiusitas dengan variabel kebermaknaan hidup linear.

Tujuan dalam menguji hipotesis adalah untuk mengetahui apakah ada hubungan atau tidak antara variabel religiusitas dengan variabel kebermaknaan hidup yang diuji dengan menggunakan teknik 
statistik yaitu uji korelasi product moment dari Karl Person melalui program komputer SPSS 21.0 for Windows. Uji hipotesis dilakukan setelah mengetahui bahwa data kedua variabel telah memenuhi syarat uji normalitas yaitu skor berdistribusi secara normal dan memiliki hubungan yang linear. Hasil analisis data menunjukkan korelasi antara variabel Religiusitas dan Kebermaknaan hidup, dengan $r_{\mathrm{xy}}=$ 0,684 dengan signifikansi $p=0,000(p<0,01)$, sehingga hipotesis yang diajukan diterima. Adapun perolehan sumbangsih religiusitas terhadap kebermaknaan hidup $\left(r_{2}\right)$ sebesar 0,467 . Religiusitas mempengaruhi kebermaknaan hidup sbesar $46,7 \%$ dan sisanya $53,3 \%$ berada pada faktor lain yang tidak diteliti pada penelitian ini. Hal ini menunjukkan bahwa ada hubungan positif antara Religiusitas dengan variabel Kebermaknaan hidup, yang berarti semakin tinggi tingkat religiusitas individu maka kebermaknaan hidupnya semakin tinggi. Begitupun sebaliknya semakin rendah tingkat religiusitas individu maka semakin rendah pula kebermaknaan hidupnya.

Skala kebermaknaan hidup memiliki deskripsi skor dalam penelitian ini secara empirik memperoleh skor minimum 45, skor maksimum 80, mean empirik 68,51 dan standar deviasi 5,725. Berdasarkan pada norma kategorisasi yang berdistribusi normal yang dapat dilihat pada skala kebermaknaan hidup, memperoleh mean empirik sebesar 68,51 yang menunjukkan bahwa skala kebermaknaan hidup berada dalam kategori sedang. Kategori skor subjek pada skala kebermaknaan hidup yang ada pada gambar tersebut dikategorisasikan berdasarkan dalam tabel sebagai berikut:

Tabel 2. Kategorisasi Skor Subjek Kebermaknaan Hidup

\begin{tabular}{llll}
\hline Norma & Kategorisasi & Frekuensi & Persentase \\
\hline $102<X \leq 120$ & Sangat Tinggi & 0 & $0 \%$ \\
$84<X \leq 102$ & Tinggi & 0 & $0 \%$ \\
$66<X \leq 84$ & Sedang & 90 & $66,7 \%$ \\
$48<X \leq 66$ & Rendah & 44 & $32,6 \%$ \\
$30<X \leq 48$ & Sangat Rendah & 1 & $0,7 \%$ \\
\hline & Total & 80 & $\mathbf{1 0 0 \%}$ \\
\hline
\end{tabular}

Skala religiusitas mempunyai definisi skor dalam penelitian ini secara empirik didapat skor minimum 119, skor maksimum 192, mean empirik 1149,63 dan standar deviasi 11,83. Berdasarkan pedoman kategorisasi yang memiliki distribusi normal dapat dilihat pada skala religiusitas, mendapatkan skor mean empirik sebesar 149,63 yang mengungkapkan bahwa skala religiusitas termasuk dalam kategori tinggi. Kategorisasi skor subjek dalam skala religiusitas terinci dalam tabel berikut:

Tabel 13. Rentang Skor Skala Religiusitas

\begin{tabular}{llll}
\hline Norma & Kategorisasi & Frekuensi & Persentase \\
\hline $170<X \leq 200$ & Sangat Tinggi & 7 & $5,2 \%$ \\
$140<X \leq 170$ & Tinggi & 104 & $77 \%$ \\
$110<X \leq 140$ & Sedang & 24 & $17,8 \%$ \\
$80<X \leq 110$ & Rendah & 0 & $0 \%$
\end{tabular}

182 
Hubungan Antara Religiusitas Dengan Kebermaknaan Hidup Narapidana di Lembaga Pemasyarakatan

(Lapas) Kelas 1 Semarang

Proyeksi, Vol. 13 (2) 2018, 177-186

$50<X \leq 80$

Sangat Rendah

0

$0 \%$

Total

80

$100 \%$

\section{Pembahasan}

Penelitian ini bertujuan untuk mengetahui apakah ada hubungan antara religiusitas dengan kebermaknaan hidup narapidana di Lembaga Pemasyarakatan (LAPAS) kelas 1Semarang. Berdasarkan hasil analisis hasil statistik diperoleh nilai $R_{x y}=0,684$ dengan taraf signifikansi $p=0,000(p<0,01)$. Hasil penelitian menunjukkan bahwa ada hubungan antara religiusitas dengan kebermaknaan hidup narapidana di Lembaga Pemasyarakatan (LAPAS) kelas 1 Semarang. Sehingga dapat dikatakan hipotesis dalam penelitian ini diterima. Religiusitas memberikan sumbangan efektif sebanyak 46,7 \% terhadap kebermaknaan hidup. Hal ini dapat dilihat dari nilai R square yaitu 0.467.

Hasil penelitian ini sejalan dengan penelitian Mahfud (2013) yang menyatakan bahwa terdapat hubungan posistif yang signifikan antara religiusitas dengan kebermaknaan hidup pada santri panti asuhan keluarga yatim Muhammadiyah Surakarta. Taylor (dalam Reza, 2013) menjelaskan seseorang yang memiliki religiusitas yang kuat mempunyai kepuasan dalam hidup dan memiliki rasa bahagia dengan diri sendiri dan semua proses hidup yang dijalani dibandingkan dengan seseorang yang tidak memiliki religiusitas mudah merasa menyerah dan putus asa atas segala masalah kehidupan yang terjadi.

Glock dan stark (Mukhlis \& Istiqomah, 2015) menjelaskan religiusitas adalah bentuk simbol, bentuk keyakinan, dan suatu perilaku keseluruhan yang bertumpu pada permasalahan-permasalahan yang perlu penghayatan untuk memperoleh makna. Religiusitas dalam kehidupan manusia mempunyai manfaat secara individual dan sosial (Ancok \& Suroso F, 2005). Taylor (Reza, 2013) menjelaskan seseorang yang memiliki religiusitas yang kuat mempunyai kepuasan dalam hidup dan memiliki rasa bahagia dengan diri sendiri dan semua proses hidup yang dijalani dibandingkan dengan seseorang yang tidak memiliki religiusitas mudah merasa menyerah dan putus asa atas segala masalah kehidupan yang terjadi.

Ibadah ialah cara mendekatkan diri kepada Tuhan dengan cara-cara yang diajarkan oleh-Nya yaitu agama (Bastaman, 2007). Ibadah yang dilakukan secara Khusyu' mampu memunculkan rasa tentram, tenang, damai, memiliki keyakinan dalam menjalani hidup dan tabah serta memberikan rasa bahagia bagi kehidupan seseorang.

Narapidana yang mempunyai religiusitas yang kuat akan cenderung mempercayai bahwa segala permasalahan dan proses hukuman yang sedang dijalani sekarang merupakan bukan suatu bentuk kegagalan dalam hidup atau hukuman dari Tuhan. Pratitis dan Setiawan (2015) mengungkapkan individu yang mempunyai religiusitas tinggi dapat mengelola atau mengontrol emosi dan bisa memaknai musibah yang terjadi secara positif, lantaran individu memiliki keyakinan yang kuat atas segala cobaan atau permasalahan yang terjadi merupakan ketentuan Tuhan. Ibadah ialah cara mendekatkan diri kepada Tuhan dengan cara-cara yang diajarkan oleh-Nya yaitu agama (Bastaman, 2007). Ibadah yang dilakukan secara Khusyu' mampu memunculkan rasa tentram, tenang, damai, memiliki keyakinan dalam menjalani hidup dan tabah serta memberikan rasa bahagia bagi kehidupan seseorang. Narapidana yang sedang menjalani masa tahanan di LAPAS melewati hari demi hari dengan terus berusaha seperti berkarya dan beribadah. Perilaku tersebut dilakukan untuk memperbaiki diri dan memperoleh ketenangan dan ketentraman dalam menjalani hidup serta makna hidup dapat 
diperoleh dalam keadaan yang tidak menyenangkan selagi seseorang itu mampu memahami hikmahnya.

Hasil analisis data skala kebermaknaan hidup pada narapidana di LAPAS Kelas 1 Semarang termasuk sedang. Hal ini diperoleh dari rentang nilai subjek (sesuai mean empirik) termasuk dalam kategori sedang yaitu 68,51. Presentase narapidana yang memiliki kebermaknaan hidup sedang $66,7 \%$ sedangkan yang mempunyai kebermaknaan hidup yang rendah sebesar $32,6 \%$ dan sebesar $0,7 \%$ memiliki kebermaknaan hidup yang sangat rendah.

Hasil analisis data skala religiusitas pada narapidana menunjukkan bahwa religiusitas tergolong tinggi. Hal tersebut didapatkan dari rentang skor subjek (sesuai mean empirik) sebesar 149,63. Presentase narapidana yang memiliki religiusitas sangat tinggi 5,2\% sedangkan yang mempunyai religiusitas yang tinggi sebesar $77 \%$ dan sebesar $17,8 \%$ memiliki religiusitas yang sedang.

\section{Kesimpulan}

Berdasarkan hasil penelitian yang telah dilakukan, dapat disimpulkan bahwa terdapat hubungan yang signifikan antara religiusitas dengan kebermaknaan hidup narapidana di Lembaga Pemasyarakatan (LAPAS) Kelas 1 Semarang. Hasil analisis menunjukkan bahwa religiusitas memberikan sumbangan efektif sebanyak $46,7 \%$ terhadap kebermaknaan hidup.

\section{Saran}

Berdasarkan pada hasil penelitian, pembahasan dan kesimpulan, ada saran-saran dapat dikemukakan untuk pihak yang terkait, seperti:

a. Saran bagi Narapidana

Para narapidana perlu untuk mempertahankan religiusitas dengan mengamalkan nilai-nilai yang diyakini kepada Tuhan seperti beribadah kepada Tuhan, membantu sesama manusia, mengamalkan nilai-nilai yang ada didalam kitab suci mengikuti kegiatan rohani dengan sepenuh hati sehingga mampu menghadapi kehidupan yang sulit di dalam penjara maupun diluar penjara nanti serta meningkatkan kesadaran dalam menemukan tujuan dan meningkatkan makna hidup

b. Saran bagi LAPAS

Untuk LAPAS perlu untuk mempertahankan kegiatan-kegiatan ibadah untuk mempertahankan religiusitas dan mengadakan program pendampingan bagi para narapidana untuk meningkatkan kesadaran dan menemukan makna hidup melalui kegiatan sesi pelatihan dan konseling, program pendampingan dengan menerapkan nilai-nilai kebermaknaan hidup supaya narapidana lebih mudah menemukan kebermaknaan hidup

c. Saran bagi peneliti selanjutnya

Bagi peneliti yang berminat melakukan penelitian dengan tema ini, disarankan untuk lebih mempertimbangkan faktor lain yang mempengaruhi kebermaknaan hidup seperti tanggung jawab, dukungan sosial, pengalaman dan kebebasan. Peneliti juga dapat mempertajam analisisnya lagi dengan memperhatikan faktor masa hukuman narapidana yang dijalani, jenis kasus serta peneliti juga dapat mmemperbanyak jumlah LAPAS yang digunakan. 
Hubungan Antara Religiusitas Dengan Kebermaknaan Hidup Narapidana di Lembaga Pemasyarakatan

\section{Daftar Pustaka}

Azwar, S. (2016). Penyusunan skala psikologi. Edisi 2. Yogyakarta: Pustaka Pelajar.

Bastaman. (2007). LOGOTERAPI:Psikologi untuk meraih makna hidup dan meraih hidup bermakna. Jakarta: PT Raja Grafindo Persada.

Bukhori, B. (2012). Hubungan kebermaknaan hidup dan dukungan keluarga dengan kesehatan mental narapidana. Jurnal ad-din 4 (1), 55-65.

Frankl, V. E. (2003). Logoterapi: Terapi psikologi melalui pemaknaan eksistensi. Yogyakarta: Kreasi Wacana.

Frazier, P., \& Steger, F. (2006). The meaning in lie questionnaire the presence ofand search for meaning in life. Journal Of Counseling Psychogy, 53(1), 80-93.

Hadi, S. (2012). Analisis regresi. Yogyakarta: Andi Offset.

Hadi, S. (2006). Metodologi research jilid III. Yogyakarta.

Hidayati, N., \& Nurhidayah, S. (2009). Hubungan antara ketabahan dan Locus of control external dengan kebermaknaan hidup pada istri yang bekerja di bagian sewing pada PT. Bosaeng Jaya Bantar Gebang Bekasi . jurnal soul, 2(2), 63-81.

Jalaluddin. (2010). Psikologi agama. Jakarta: Rajawali Pers.

Koeswara, E. (1992). Logoterapi:Psikoterapi viktor frankl. Yogyakarta: Kanisius.

Mahfud. (2013). Hubungan religiusitas dengan kebermaknaan hidup pada santri panti asuhan keluarga yatim Muhammadiyah Surakarta. Skripsi (tidak diterbitkan) Fakultas Agama Islam Universitas Muhammadiyah Surakarta.

Moeljatno. (2008). Asas- asas hukum pidana. Jakarta: Bina Aksara.

Mukhlis, \& Istiqomah, i. (2015). Hubungan antara religiusitas dengan kepuasan perkawinan. Jurnal Psikologi, 11(2), 71-78.

Muljono, W. (2012). Pengantar teori kriminologi. Yogyakarta: Pustaka Yustisia.

Nashori, F., \& Diana, R. (2002). Mengembangkan kreativitas dalam perspektif psikologi Islam. Yogyakarta: Menara kudus.

Pinasthika. (2013). Pemenuhan hak-hak Narapidana selama menjalani masa pidana di Lembaga pemasyarakatan kelas IIA Yogyakarta. Skripsi (tidak diterbitkan) Universitas Negeri Yogyakarta.

Pratitis, T. N., \& Setiawan, A. (2015). Religiusitas, dukungan sosial dan resiliensi korban 
lumpur lapindo Sidoarjo. Jurnal Psikologi Indonesia, 4 (2), 137-144.

Pratiwi, L. R. (2011). Hubungan kebermaknaan hidup dengan self esteem pada penghuni pusat rehabilitasi narkoba rumah damai. Skripsi (tidak diterbitkan) Fakultas IImu Pendidikan Jurusan Psikologi Universitas Negeri Semarang.

Prihastiwi, W. J. (1994). Kebermaknaan hidup lanjut usia pensiun dikaitkan dengan perilaku koping, religiusitas dan tempat tinggal di Surabaya. tesis (tidak diterbitkan) Fakultas Psikologi Universitas Gajah Mada.

Priyatno. (2006). Sistem pelaksanaan pidana di Indonesia. Bandung: PT.Refika Aditama.

Rosyidi, H. (2015). Religiusitas dan kebermaknaan hidup menjelang masa pensiun. Jurnal Bimbingan dan Konseling Islam, 5(1), 67-92.

Saputri, A. S., Hardyono, \& Karyanta, A. N. (2011). hubungan religiusitas dan dukungan sosial dengan psychological well being santri kelas VIII Pondok pesantren Tahfidzul Qur'an Ibnu Abbas Klaten . Jurnal Program study psikologi fakultas kedokteran .

Schultz, D. (1995). Psikologi pertumbuhan model-model kepribadian sehat. Yogyakarta: Kanisius.

Sugiyono. (2013). Metode penelitian pendidikan kuantitatif, kualitatif dan R\&D. Bandung: Alfabeta.

Thouless, R. H. (2000). Pengantar Psikologi Agama. Jakarta: Rajawali Pers.

Tobing, D. H., \& Dewi, S. (2014). Kebermaknaan Hidup pada anak Pidana di Bali. Jurnal Psikologi Udayana, 1(2), 322-334.

Ula, T. (2014). Makna hidup bagi narapidana. Jurnal Hisbah, 11(1), 16-35.

Undang-undang dasar negara republik Indonesia tahun 1945. (2014). Surabaya: Anugerah.

Utami, M., \& Amawidyawati, S. (2012). Religiusitas dan Psychological well- being pada korban gempa. Jurnal Psikologi, 34(2), 164-176.

Uyun, Q., \& Gumilar, U. F. (2009). kebersyukuran dan kebermaknaan hidup pada mahasiswa. Psikologika, 14(1), 65-69. 